\title{
Adult Population Development of Grapholita molesta (Busck, 1916) (Lepidoptera: Tortricidae) on Different Fruit Species and Locations
}

\author{
Ali Kürşat Şahin * iD Ali Özpinar \\ Çanakkale Onsekiz Mart University, Faculty of Agriculture, Department of Plant Protection, 17100, Çanakkale \\ *Corresponding author's: aksahin@ comu.edu.tr
}

Geliş Tarihi: 21.10.2021

Kabul Tarihi: 18.11.2021

\begin{abstract}
Oriental fruit moth, Grapholita molesta Busck (Lepidoptera: Tortricidae) is an important fruit pest with a wide range of host in many fruit producing countries. This study was conducted with the purpose of determining the adult population development of G. molesta on different fruit species in different locations in Çanakkale province of Turkey. With this purpose pheromone traps were placed in peach, cherry and apricot orchards in City center, Biga, Lapseki and Bayramiç districts of Çanakkale province. The traps were checked weekly and the number of adult G. molesta in traps were recorded. At the end of the study, the pest is confirmed to exist in all fruit producing areas of Çanakkale province. First adult emergence was at early May with the adult population continuing until October. The pest has 2-3 generations throughout production season, which may change with relation to fruit species and location. According to the statistical analysis of the data, both location and fruit species have significant effects on adult population development of the pest with the highest population occurring in peach as the fruit species and Lapseki district as the location. It is thought that the differences in adult population density and development between orchards with the same fruit species is caused by different fruit cultivars used in orchards, different treatments by farmers and climate differences.
\end{abstract}

Keywords: Oriental fruit moth, Grapholita molesta, Host species, Adult population

\section{Farklı Meyve Türlerinde ve Lokasyonlarda Grapholita molesta (Busck, 1916) (Lepidoptera: Tortricidae)'nın Ergin Popülasyon Gelişmesi \\ $\ddot{O}_{z}$}

Geniş bir konukçu aralığına sahip olan doğu meyve güvesi, Grapholita molesta Busck (Lepidoptera: Tortricidae) birçok meyve üretimi yapılan ülkede önemli bir meyve zararlısıdır. Bu çalışma G. molesta'nın Çanakkale İli'nde farklı meyve türlerinde ve farklı lokasyonlarda ergin popülasyon gelişmesinin belirlenmesi amacıyla yapılmıştır. Bu amaçla, Merkez, Biga, Lapseki ve Bayramiç ilçelerinde şeftali, kiraz ve kayısı bahçelerine feromon tuzakları yerleştirilmiş̧ir. Tuzaklar haftalık olarak kontrol edilerek tuzaklara yakalanan ergin sayıları kaydedilmiştir. Çalışma sonucunda zararlının meyve üretimi yapılan bütün ilçelerde bulunduğu ve ilk erginlerin genel olarak mayıs başında tuzaklara yakalandığı ve ekim ayına kadar ergin çıkışının devam ettiği görülmüştür. Popülasyon gelişmesi göre meyve türlerine ve lokasyona göre değişmekle birlikte zararlı yaklaşı 2-3 nesil oluşturmaktadır. Gerçekleştirilen istatistiksel analiz sonuçlarına göre zararlının popülasyon yoğunluğu üzerinde lokasyonun ve meyve türünün etkisi olduğu ve popülasyonun meyve türü olarak en yoğun şeftalide, lokasyon olarak ise Lapseki ilçesinde görüldüğü sonucuna varılmıştır. Aynı meyve türüne sahip bahçelerde görülen popülasyon yoğunluğu ve popülasyon gelişmesindeki farklılıkların bahçe tesisinde kullanılan meyve çeşidi, üreticilerin farklı uygulamaları ve farklı lokasyonlardaki iklimsel farklılıklardan kaynaklandığı düşünülmektedir.

Anahtar Kelimeler: Doğu meyve güvesi, Grapholita molesta, Konukçu türler, Ergin popülasyonu

\section{Introduction}

Oriental fruit moth, Grapholita molesta (Busck) (Lepidoptera: Torticidae) is a polyphagous fruit pest originated from China like its primary host, peach. At present, G. molesta is an important pest of many fruit species in Europe, Asia, America, Africa and Australia continents with considerable damage (Rothschild and Vickers, 1991; Choi et al., 2008; Kirk et al., 2013). Other than peach, hosts of the pest include pear, apple, cherry, apricot and plum (Chapman and Lienk, 1971; Sarker and Lim, 2019). The pest has 3-7 generations per year (Yang et al., 2001, 2002; Kim et al., 2004, 2009; Damos and Savopoulou-Soultani, 2010, Özpınar et al., 2012; Du et al., 2015). Because of its high reproduction rate and considerable host number, it is an important fruit pest. 
Females of G. molesta can start laying eggs 2-5 days after emerging from pupa and can lay around 144-333 eggs throughout their lives and mean adult longevity is 20 days (Arioli et al., 2010; Botton et al., 2011). Maximum oviposition period can change between 4-9 days after mating (Gonzales, 1993). Eggs of the pest are around $0,7 \mathrm{~mm}$ in size with an oval shape and white to gray white in color, with the color changing to a darker tone as the embryo develops. Mean egg development time is reported around 4 days (Neto Silva et al., 2010). Larva of G. molesta has 5 instars, with white-cream color in the first 3 instars and pink-white color in the last 2 instars. Adults of G. molesta are dark gray in color with light colored bands on the wings. Adult males are smaller than females. Body length of adults is 10-15 mm, while body width is 6-7 mm (Salles, 1991; Bentacourt and Scatoni, 1995).

Grapholita molesta overwinters as mature larva in a cocoon in the cracks of tree bark. With spring, mature larvae pupate in the overwintering location and adults generally start to emerge at the end of March or the beginning of April (Özpınar et al., 2012, 2014). Females lay their eggs at the tip of fresh shoots (Yang et al., 2001). Larvae of the pest feed on the shoots by burrowing into the tip and cause desiccation of the shoot. In high populations, mass desiccation of shoots may cause excessive shoot development, which may lead to a bush like image on the tree. As the fruits start to develop, larvae burrows into the fruit through the bottom of fruit stalk and form galleries towards the seed chamber. Mature larvae emerge from the fruit by penetrating the fruit skin, thus damaging the fruit and significantly decreasing its value. With the lack of management applications, the pest can cause high amounts of damage in orchards (Yang et al., 2001).

As many other pests, farmers prefer chemical control against G. molesta (Stearns, 1920; Rothschild and Vickers, 1991; Kanga et al., 2003; Kovanci and Walgenbach, 2005; Elbert et al., 2008). Intensive and untimely chemical applications from different insecticide groups have caused resistance in the pest, which leads to a lower effect of chemical control (Jones et al., 2010; Siegwart et al., 2011). Thus, it is important to determine the changes in the population of the pest to decide the suitable period of control applications. Management applications against this pest are generally geared towards the control of the eggs and the larvae. However, population development data is mostly collected from adults, because determining the population development of eggs and larvae is a very labor-intensive process caused by their small size. Pheromone traps are the most used tools for determining adult population development. Thus, the purpose of this study was to determine the adult population development of $G$. molesta on peach, cherry and apricot produced in different district of Çanakkale in 2013 and 2014.

\section{Materials and Methods}

The main materials of the study were adults of G. molesta and the pheromone traps used to capture the adults. The study was conducted in peach, cherry and apricot orchards of Central, Lapseki, Biga, Bayramiç and Ezine districts of Çanakkale province in Turkey in 2013 and 2014. The selected orchards were in a distance of at least $1 \mathrm{~km}$ from other orchards in the area and established from one fruit species. Also, all orchards were at least 5 da in size. The study was conducted in 5 peach, 3 cherry and 2 apricot orchards (Table 1).

The adult population of $G$. molesta was determined with delta type pheromone traps from Trece Incorporated. The traps were placed in the orchards in April and May in 2013 and in April in 2014. One trap per each orchard was placed at 1-1.5 m height on a tree at the center of the orchard, with the predominant wind direction in mind. The traps were controlled weekly and the number of adults in each trap was recorded. After each control, the traps were cleaned, and damaged sticky panels were changed with new ones. In addition, the lures were changed every 5-6 weeks, as they lose their pheromone load. Trap controls were continued until the end of September in 2013 and the $2^{\text {nd }}$ week of November in 2014. 
Table 1. Orchard locations, cultivars and trap placement dates

\begin{tabular}{|c|c|c|c|c|}
\hline Location & Fruit species & Coordinates & Cultivar & Trap placement date \\
\hline \multirow[t]{2}{*}{ Biga } & Peach & $40^{\circ} 23^{\prime} 31.47^{\prime \prime} \mathbf{N}-27^{\circ} 15^{\prime} 53.90^{\prime \prime} \mathbf{E}$ & Redhaven & $26.04 .2013 / 10.04 .2014$ \\
\hline & Cherry & $40^{\circ} 21^{\prime} 48.76^{\prime \prime} \mathbf{N}-27^{\circ} 17^{\prime} 13.34^{\prime \prime} \mathbf{E}$ & Ziraat 900 & $26.04 .2013 / 10.04 .2014$ \\
\hline \multirow[t]{2}{*}{ Bayramiç } & Peach & $39^{\circ} 45^{\prime} 45.09^{\prime \prime} \mathbf{N}-26^{\circ} 27^{\prime} 27.12^{\prime \prime} \mathbf{E}$ & Glohaven & 06.05.2013/ 10.04.2014 \\
\hline & Cherry & $39^{\circ} 49^{\prime} 36.71^{\prime \prime} \mathbf{N}-26^{\circ} 39^{\prime} 37.03^{\prime \prime} \mathbf{E}$ & Ziraat 900 & 06.05.2013/ 10.04.2014 \\
\hline \multirow[t]{2}{*}{ Ezine } & Cherry & $39^{\circ} 44^{\prime} 47.48^{\prime \prime} \mathbf{N}-26^{\circ} 22^{\prime} 06.99^{\prime \prime} \mathbf{E}$ & Ziraat 900 & 06.05.2013 / 10.04.2014 \\
\hline & Apricot & $39^{\circ} 45^{\prime} 14.92^{\prime \prime} \mathbf{N}-26^{\circ} 20^{\prime} 50.92^{\prime \prime} \mathbf{E}$ & Tom Cot & 06.05.2013/ 10.04.2014 \\
\hline Central (Dardanos) & Peach & $40^{\circ} 04^{\prime} 20.30^{\prime \prime} \mathbf{N}-26^{\circ} 21^{\prime} 52.34^{\prime \prime} \mathbf{E}$ & Redhaven & 30.04.2013 / 10.04.2014 \\
\hline Central (Kalabaklı) & Peach & $40^{\circ} 05^{\prime} 07.33^{\prime \prime} \mathbf{N}-26^{\circ} 24^{\prime} 46.00^{\prime \prime} \mathbf{E}$ & Redhaven & $-/ 10.04 .2014$ \\
\hline Central (Kepez) & Apricot & $40^{\circ} 04^{\prime} 59.49^{\prime \prime} \mathbf{N}-26^{\circ} 33^{\prime} 44.78^{\prime \prime} \mathbf{E}$ & Roxana & $-/ 10.04 .2014$ \\
\hline Lapseki (Çardak) & Peach & $40^{\circ} 23^{\prime} 54.68^{\prime \prime} \mathbf{N}-26^{\circ} 45^{\prime} 47.83^{\prime \prime} \mathbf{E}$ & J.H. Hale & 03.05.2013/ 10.04.2014 \\
\hline Lapseki (Kangırlı) & Peach & $40^{\circ} 14^{\prime} 44.71^{\prime \prime} \mathbf{N}-26^{\circ} 33^{\prime} 54.07^{\prime \prime} \mathbf{E}$ & Glohaven & 03.05.2013/ 10.04.2014 \\
\hline
\end{tabular}

\section{Statistical Analysis}

Data from the study were analyzed in Minitab 17 statistical software with one way ANOVA to determine if there is any differences between the means. Because the data was gathered by counting the individuals and the presence of " 0 " values in the datasets, 0,5 added to all data and they were transformed by square root transformation before the analysis. In the case of a significant difference between means, TUKEY multiple comparison test was used to determine which means are different than the others.

\section{Results}

\section{Number of Adults in Traps}

The total numbers of adults captured in traps in 2013 and 2014 are shown in Table 2. A total of 8193 G. molesta adults were captured in all locations and fruit species, in 2013 and 2014. Generally, the number of adults captured in traps was higher in 2014, probably caused by the addition of two orchards and earlier placement date of the traps in the orchards. In 2013, the number of adults captured in peach orchards per trap $(346,8)$ was higher than in cherry orchards $(292,6)$ and the apricot orchard (63). Similarly, number of adults per trap was higher in peach orchards $(621,5)$ than cherry orchards $(521,3)$ and apricot orchards $(112,5)$.

Table 2. Total number of adults captured in traps in 2013 and 2014

\begin{tabular}{llll}
\hline Fruit Species & Locations & 2013 & 2014 \\
\hline & Biga & 195 & 733 \\
& Bayramiç & 439 & 705 \\
Peach & Lapseki (Çardak) & 489 & 851 \\
& Lapseki (Kangrrlı) & 466 & 776 \\
& Central Dardanos) & 145 & 200 \\
& Central (Kalabakli) & - & 464 \\
& Peach Total & $\mathbf{1 7 3 4}$ & $\mathbf{3 7 2 9}$ \\
Cherry & Biga & 351 & 386 \\
& Bayramiç & 371 & 582 \\
& Ezine & 156 & 596 \\
Apricot & Cherry Total & $\mathbf{8 7 8}$ & $\mathbf{1 5 6 4}$ \\
& Ezine & 63 & 135 \\
Total & Central (Kepez) & - & 90 \\
& Apricot Total & $\mathbf{6 3}$ & $\mathbf{2 2 5}$ \\
& & $\mathbf{2 6 7 5}$ & $\mathbf{5 5 1 8}$ \\
\hline
\end{tabular}

\section{Adult Population Development in 2013}

In peach orchards, adult population of $G$. molesta has changed throughout the study period with time in 2013 (Figure 1). Adults were first captured in the traps at the beginning of May with the highest adult number was in the trap in Lapseki (Kangirll) with 24 individuals, while other locations had 5-7 individuals.

In Biga orchard, adult population was generally low until the $10^{\text {th }}$ of July, when the number of adults in the traps has started to increase. The only peak point in this trap was recorded on $17^{\text {th }}$ of July with 73 adults and the population has decreased as the season progressed until mid-September. In Bayramiç orchard, number of adults reached to the first peak value on $5^{\text {th }}$ of June with 110 individuals and then dropped until the date of $22^{\text {nd }}$ of August, with some fluctuations. Another peak was 
discovered on $28^{\text {th }}$ of August with 58 individuals, which was followed by a decrease in population until $18^{\text {th }}$ of September. No adults were captured in this trap after this date. In Lapseki (Çardak) orchard, population was low in the first four weeks. The number of adults in the trap has started to increase at the beginning of June and has increased until the only peak point of 96 adults on $21^{\text {st }}$ of August. Population was high in the following two weeks, but rapidly fell as September progressed. In Lapseki (Kangirl1) orchard, first peak was found on $17^{\text {th }}$ of May with 32 adults, and the second peak was on $21^{\text {st }}$ of August with 93 adults, the same date as the peak point of the other trap in Lapseki. There was another high number of adults on $7^{\text {th }}$ of August with 51 adults, but we considered the highest number as the second peak. Because the dates were near to each other and there was a low number of adults in the trap on the following week, which was caused by the trap falling onto the ground during farmer practices. In Central (Dardanos) orchard, the adult population was low at the beginning of the study. Similar to the trap in Biga, the number of adults captured in the trap has started to increase towards July and has reached the only peak point of this trap on $10^{\text {th }}$ of July with 23 adults. Population in this orchard was generally lower than other orchards.

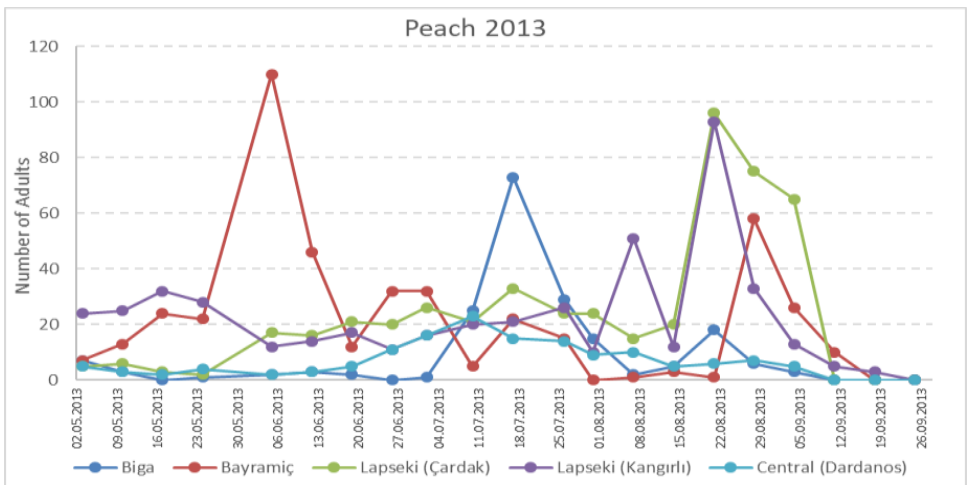

Figure 1. Adult population development of Grapholita molesta in peach orchards in 2013

In cherry orchards, adult population of G. molesta was mostly higher at the first half of the study season (Figure 2). The number of adults at the beginning of the study were higher in Biga and Bayramiç than Ezine.

In Biga orchard, the peak point was recorded on $12^{\text {th }}$ of June with 76 adults and the population has decreased until the end of August, with small fluctuations. In Bayramiç orchard, the peak in the population of the pest was on $12^{\text {th }}$ of August with 62 adults, same date as the trap in Biga orchard. In Ezine orchard, the population was generally low until $26^{\text {th }}$ of June with the peak point was being recorded on $10^{\text {th }}$ of July with 66 adults. Population development was slower than other orchards in Ezine.

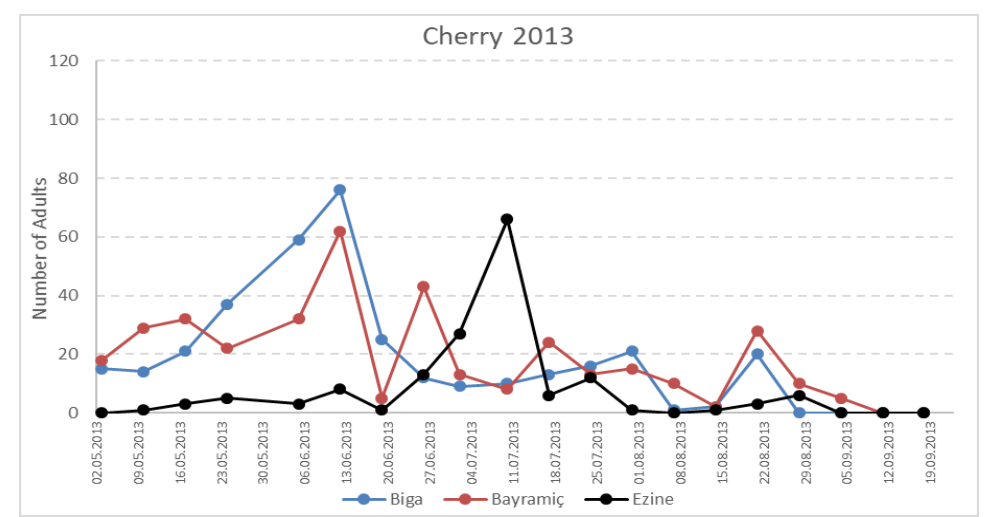

Figure 2. Adult population development of Grapholita molesta in cherry orchards in 2013 
In the apricot orchard in Ezine district, the population of $G$. molesta adults was very low, compared to the other districts (Figure 3). Population did not make any significant changes throughout the season and there was no visible peak points.

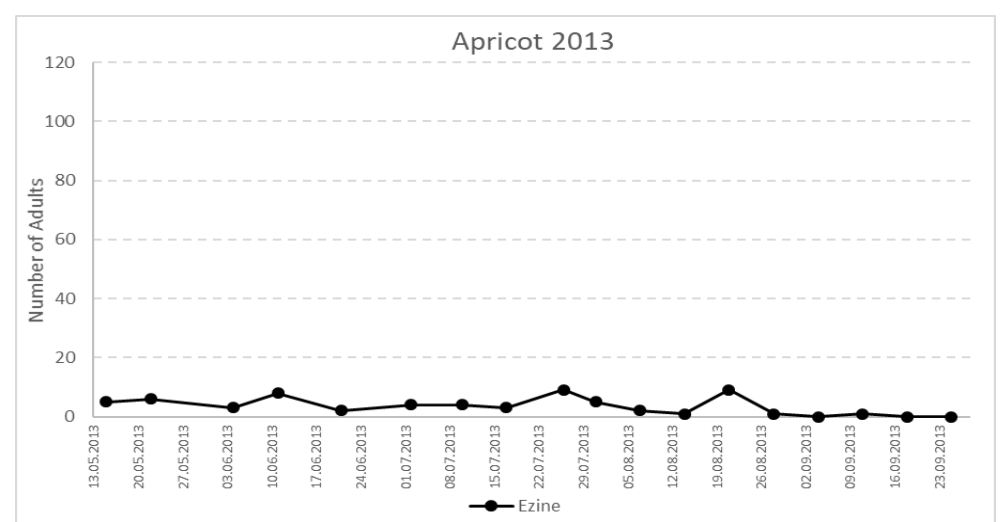

Figure 3. Adult population development of Grapholita molesta in the apricot orchard in 2013

\section{Adult Population Development in 2014}

In 2014, first G. molesta adults were captured in traps on $17^{\text {th }}$ of April. Contrary to the previous year, adults were mostly captured in the latter half of the study season in peach orchards. Number of adults captured in the first sampling was similar in all traps in peach orchards of different locations.

In Biga orchard, adult population was mostly stable until $3^{\text {rd }}$ of July, when it started to increase and reached a peak point on $24^{\text {th }}$ of July with 83 adults, which was followed by another peak on $24^{\text {th }}$ of August with 82 adults. In Bayramiç, there were also two peak points similar to Biga however, first peak point was earlier in the season on $29^{\text {th }}$ of May with 66 adults and the second peak was on $17^{\text {th }}$ of August with 89 adults. In Lapseki orchards, population development of G. molesta adults were pretty similar throughout the season. In both orchards, there was one clear peak point on $10^{\text {th }}$ of August with 113 adults in Çardak orchard and with 94 adults in Kangırlı orchard. In Central (Dardanos) orchard, population was generally lower than other peach orchards and there were not any clear peak points, however adult population was highest on $3^{\text {rd }}$ of July with 25 adults. In the other orchard in Central district (Kalabakl1), there were two peak points, with the first one being on $5^{\text {th }}$ of June with 35 adults and the second one being on $10^{\text {th }}$ of August with 58 adults.

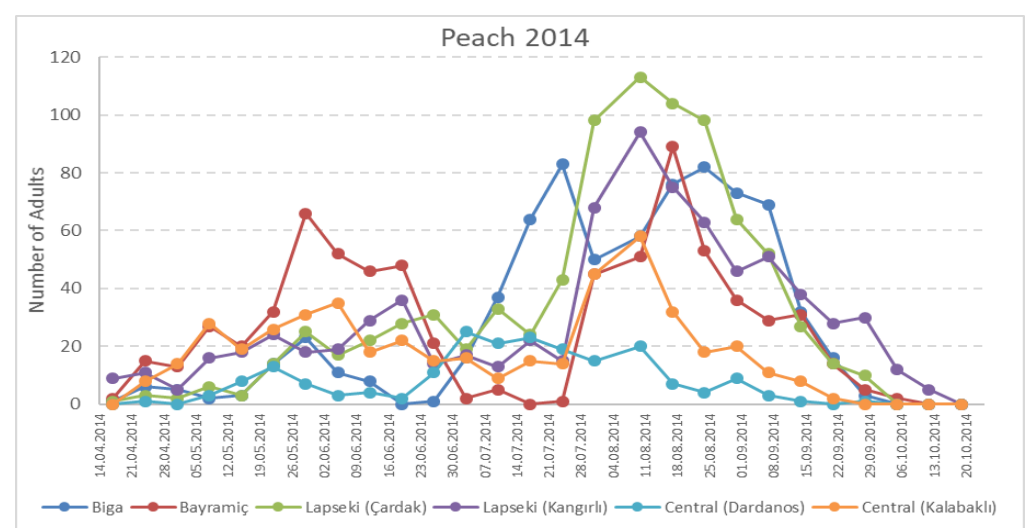

Figure 4. Adult population development of Grapholita molesta in peach orchards in 2014

Similar to peach orchards, adult population of G. molesta in cherry orchards were generally denser on the second half of the season in 2014.

In Biga orchard, adult population increased after capturing of the first adults, until 33 adults on $19^{\text {th }}$ of June, when it started do decrease again. The second population growth peaked on $17^{\text {th }}$ of August with 41 adults. In Bayramiç, first peak point was on $3^{\text {rd }}$ of July with 53 adults, which was 
followed by the second peak on $24^{\text {th }}$ of August with 62 adults. In Ezine, first peak point was much earlier than the other cherry orchards, on $15^{\text {th }}$ of May with 31 adults, with the second peak being closer to others, on $31^{\text {st }}$ of July with 82 adults.

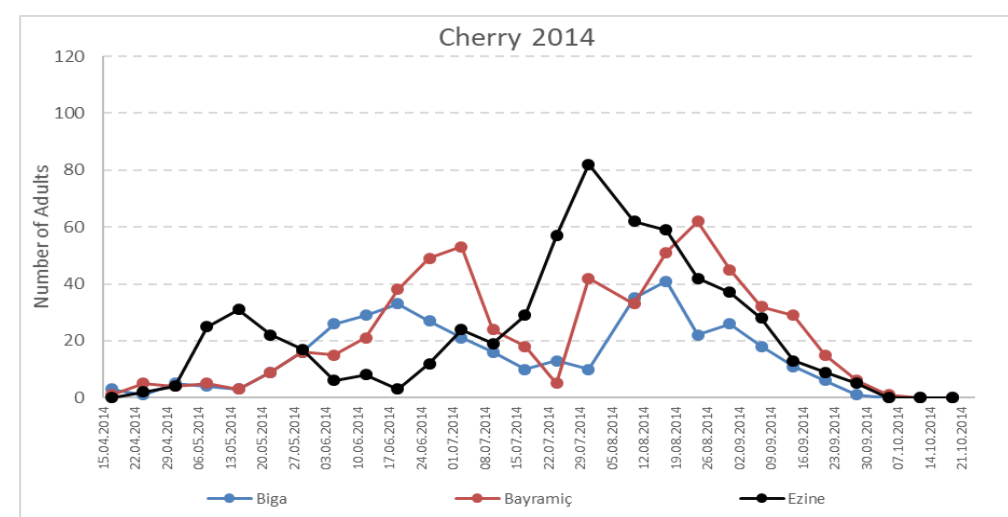

Figure 5. Adult population development of Grapholita molesta in cherry orchards in 2014

Adult population development of the pest in both apricot orchards were much lower than the other fruit species in 2014. Similar to the previous year, population was generally stable and did not fluctuate in both orchards. Highest number of adults in Ezine orchard was 13 on $29^{\text {th }}$ of May and it was 17 on $21^{\text {st }}$ of August.

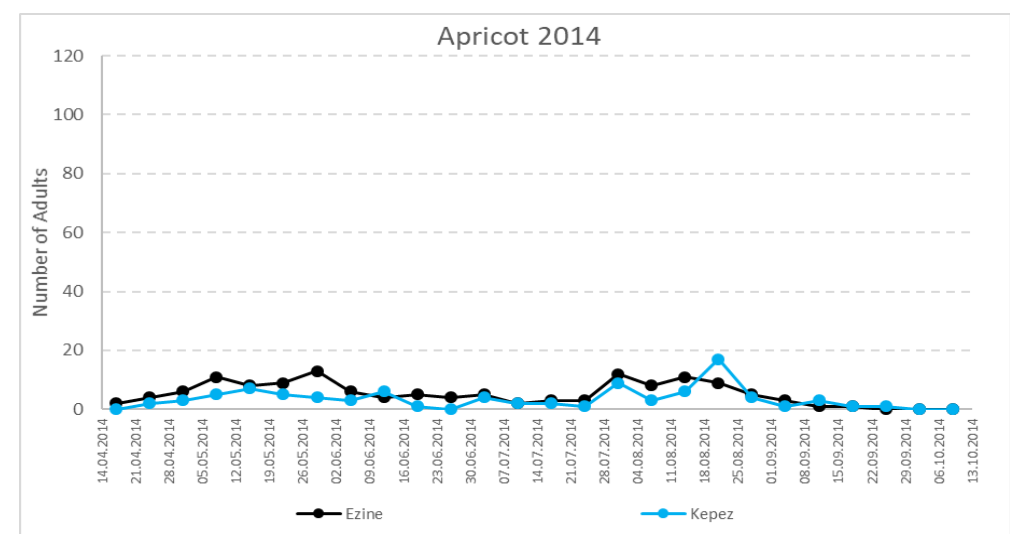

Figure 6. Adult population development of Grapholita molesta in the apricot orchard in 2014

\section{Differences Among Grapholita molesta Adult Populations}

Statistical differences between G. molesta adult populations from different fruit species and different locations were determined with the statistical analysis of the data from both years. The results are shown in tables 3, 4 and 5 for 2013 and in tables 6, 7, 8 and 9 for 2014.

\section{Study conducted in 2013}

In 2013, mean number of adults captured in peach orchards was significantly higher than apricot orchards, while there was not any statistically significant difference between peach and cherry or between cherry and apricot $(\mathrm{F}=4,01, \mathrm{df}=2, \mathrm{P}=0,020)$ (Table 3$)$.

Table 3. Mean number of Grapholita molesta adults captured in traps at different fruit species in 2013 (Mean \pm Standart Error)

\begin{tabular}{lll}
\hline Peach $(\mathrm{n}=105)$ & Cherry $(\mathrm{n}=60)$ & Apricot $(\mathrm{n}=18)$ \\
$16.51 \pm 2.05 \mathrm{a}$ & $14.63 \pm 2.26 \mathrm{ab}$ & $3.50 \pm 0.71 \mathrm{~b}$ \\
\hline
\end{tabular}

Note: The means in the same row followed by different letters are significantly different at $\mathrm{P}<0,05$

In peach, the highest mean number of adults were captured in Lapseki (Kangirli) orchard in 2013, with no significant difference from Bayramiç and Lapseki (Çardak) orchards. While, mean number of adults in Biga and Central (Dardanos) orchards were not different from each other, and 
from Bayramiç and Lapseki (Çardak) orchards, both orchards had significantly lower mean number of adults than Lapseki (Kangirl1) orchard $(\mathrm{F}=4,28, \mathrm{df}=4, \mathrm{P}=0,003)$ (Table 4).

Table 4. Mean number of Grapholita molesta adults captured in peach orchards at different locations in 2013 (Mean \pm Standart Error $)(\mathrm{n}=21)$

\begin{tabular}{ccccc}
\hline Biga & Bayramiç & Lapseki (Çardak) & Lapseki (Kangirli) & Central (Dardanos) \\
$9.29 \pm 3.68 \mathrm{~b}$ & $20.90 \pm 5.65 \mathrm{ab}$ & $23.29 \pm 5.59 \mathrm{ab}$ & $22.19 \pm 4.36 \mathrm{a}$ & $6.90 \pm 1.32 \mathrm{~b}$ \\
\hline
\end{tabular}

Note: The means in the same row followed by different letters are significantly different at $\mathrm{P}<0,05$

In cherry, Bayramiç orchard had the highest mean number of adults but there was no significant difference from Biga orchard, while Ezine had significantly lower mean number of adults. Also, the difference between the number of adults in Big and Ezine was not significant either $(\mathrm{F}=3,75$, $\mathrm{df}=2, \mathrm{P}=0,030)($ Table 5).

Table 5. Mean number of Grapholita molesta adults captured in cherry orchards at different locations in 2013 (Mean \pm Standart Error $)(\mathrm{n}=20)$

\begin{tabular}{ccc}
\hline Biga & Bayramiç & Ezine \\
$17.55 \pm 4.46 \mathrm{ab}$ & $18.55 \pm 3.54 \mathrm{a}$ & $7.80 \pm 3.39 \mathrm{~b}$ \\
\hline
\end{tabular}

Note: The means in the same row followed by different letters are significantly different at $\mathrm{P}<0,05$

\section{Study conducted in 2014}

In 2014, mean numbers of adults has significantly changed with the fruit species. Mean number of adults captured in peach and cherry orchards was not significantly different from each other, while mean number from apricot traps was significantly lower than the other fruit species $(\mathrm{F}=16,66, \mathrm{df}=2, \mathrm{P}=0,000)$ (Table 6).

Table 6. Mean number of Grapholita molesta adults captured in traps at different fruit species in 2014 (Mean \pm Standart Error)

\begin{tabular}{ccc}
\hline Peach $(\mathrm{n}=162)$ & Cherry $(\mathrm{n}=81)$ & Apricot $(\mathrm{n}=52)$ \\
$23.02 \pm 1.98 \mathrm{a}$ & $19.31 \pm 2.05 \mathrm{a}$ & $4.33 \pm 0.53 \mathrm{~b}$ \\
\hline
\end{tabular}

Note: The means in the same row followed by different letters are significantly different at $\mathrm{P}<0,05$

In peach orchards, there was a significance difference between the mean numbers of adults from different locations in 2014. The mean number of adults from Central (Dardanos) orchard was significantly lower than all other orchards, except the other orchard in Central district (Kalabakl1). Also, the difference between Biga, Bayramiç, both Lapseki orchards and Central (Kalabakli) was not statistically significant $(\mathrm{F}=4,15, \mathrm{df}=5, \mathrm{P}=0,001)$ (Table 7).

Table 7. Mean number of Grapholita molesta adults captured in peach orchards at different locations in 2014 (Mean \pm Standart Error) $(\mathrm{n}=27)$

$\begin{array}{cccccc}\text { Biga } & \text { Bayramiç } & \text { Lapseki (Çardak) } & \text { Lapseki (Kangırlı) } & \text { Central (Dardanos) } & \text { Central (Kalabaklı) } \\ 27.15 \pm 5.78 \mathrm{a} & 26.11 \pm 4.59 \mathrm{a} & 31.52 \pm 6.65 \mathrm{a} & 28.74 \pm 4.52 \mathrm{a} & 7.41 \pm 1.56 \mathrm{~b} & 17.19 \pm 2.78 \mathrm{ab}\end{array}$

Note: The means in the same row followed by different letters are significantly different at $\mathrm{P}<0,05$

There was no statistically significant difference between mean number of adults from different locations in both cherry $(\mathrm{F}=0,75, \mathrm{df}=2, \mathrm{P}=0,475)$ (Table 8$)$ and apricot $(\mathrm{F}=2,14, \mathrm{df}=1, \mathrm{P}=0,150)$ (Table 9) in 2014.

Table 8. Mean number of Grapholita molesta adults captured in cherry orchards at different locations in 2014 (Mean \pm Standart Error) $(\mathrm{n}=27)$

\begin{tabular}{ccc} 
& & Ezine \\
Biga & Bayramiç & $22.07 \pm 4.26 \mathrm{a}$ \\
\hline $14.30 \pm 2.34 \mathrm{a}$ & $21.56 \pm 3.69 \mathrm{a}$ & 22.07 \\
\hline
\end{tabular}

Note: The means in the same row followed by different letters are significantly different at $\mathrm{P}<0,05$ 
Table 9. Mean number of Grapholita molesta adults captured in apricot orchards at different locations in 2014 (Mean \pm Standart Error) $(\mathrm{F}=2,14, \mathrm{df}=1, \mathrm{P}=0,150) \quad(\mathrm{n}=26)$

\begin{tabular}{cc}
\hline Ezine & Central (Kepez) \\
$5.19 \pm 0.76 \mathrm{a}$ & $3.46 \pm 0.71 \mathrm{a}$ \\
\hline
\end{tabular}

Note: The means in the same row followed by different letters are significantly different at $\mathrm{P}<0,05$

\section{Discussion}

The analysis of the results of our study shows that G. molesta adult population is generally higher in peach and cherry than apricot. Populations were not significantly different in between peach and cherry in both years, while population in apricot orchards was quite lower than the others. Similarly, Amat et al. (2001) have also reported higher populations in peach orchards than apple orchards with 4 generations per year in apple and 5 generations in peach.

Generally, adult population of G. molesta was high around May and declined throughout the season until June, when it started to increase again. This early increase in adult numbers is thought to be the result of mass emergence of adults in the early season. Even though the exact reason of this phenomenon is not known it is theorized that in some years, some of the larvae from the interlocking generations may diapause and overwinter with the normal overwintering population, thus increasing the number of new adults in spring. Another opinion is the females laying eggs to compensate the loss of population during the harvest season on other late maturing host plants around to increase the number of overwintering offspring (Borchert et al., 2004).

In peach, the number of adults captured in traps generally showed two peak points around July and August, which is synchronize with the development of mature fruits. Also, G. molesta population highly fluctuated in Lapseki and Bayramiç district, where there is intensive peach production. With this results in mind, we concluded that the pest has 2-3 generations in this region. Similarly, Özpınar et al. (2014) have reported two peak points in April and August in Çanakkale province. Also, according to Kyparissoudas (1989) the pest has its first flight around early-April to late-May, which is close to our results. Gençsoylu et al. (2006) have reported the first flight in mid-May and 4 generations per year in Aydın province, where the climate is much warmer than Çanakkale.

Grapholita molesta adult population has increase in the period when fruits mature and has started to decline after the harvest season. However, there was a high number of adults in the trap in Bayramiç in the early season. Also, the number of adults captured in Bayramiç was higher than other locations. As seen in table 1, the peach orchard in Bayramiç consist of Glohaven cultivar. This cultivar may be a result of this situation because; according to Kovanc1 et al. (2006), G. molesta adults prefer Glohaven to other cultivars such as Redhaven and Dixired. Also, Myers et al. (2006) have reported lower larval survival rate on Redhaven than other cultivars.

In cherry, first $G$. molesta adults generally have been captured in mid-May and continued until September with 1-2 peak points. Similarly, Ertop and Özpınar (2007) have reported first G. molesta adult flight in May. The study by Özpinar et al. (2012) suggest that the pest has 5-6 generationsin cherry and cherry-apple mixed orchards in 2008 and 2009. We think that the high amount of adult flight in our study is caused by the continuation of the population from the difference between the periods of harvest in apple and cherry in the region.

In Biga and Bayramiç, adult numbers in traps generally increased in June, while this increase was in mid-July in Ezine district. All cherry orchards were laid out with Ziraat 900 cultivar, so this difference in peak periods is not caused by cultivar differences. According to the climate data, daily mean temperature was higher in Ezine than Biga and Bayramiç, while relative humidity was higher in Biga and Bayramiç. This difference in climatic conditions may be the reason of the different peak periods.

\section{Conclusions}

According to our results, G. molesta adult population was found to be higher in peach and cherry orchards, rather than apricot. However, the pest was present in all survey sites with a high enough population to cause significant damage, especially in harvest season. Also, the emergence period and following flight periods of the pest was determined on different fruit species and locations. When these results and the wide host range of the pest is evaluated together, it is apparent that it is 
important to control this pest in Çanakkale region. Timing of pest management applications is important for all pest species, but it is especially essential in regions like Çanakkale, where many different fruit species with different maturation periods are produced together, sometimes even in the same orchard. Thus, to determine the optimum control application period, we need first emergence dates after overwintering, changes in the population related to time and climate conditions and the relationship between the pest and the phenology of the host.

Data from our study is useful to determine the suitable period for control applications of the pest in the region and other regions with similar climate conditions. There are not many studies about the population development of G. molesta on different hosts in literature. Thus, we think the results of this study may be an important addition to literature and to further studies about G. molesta.

\section{Acknowledgements}

This manuscript is written from a part of the doctoral thesis of the first author.

\section{References}

Amat, C., Bosch-Serra, D., Avilla, J., Colomar, L.A.E., 2001. Different population phenologies of Grapholita molesta (Busck) in two hosts and two nearby regions in the NE of Spain. Insects. 12: 612.

Arioli, C.J., Garcia, M.S., Zart, M., Botton, M., 2010. M. Biologia da mariposa oriental em dieta artificial à base de Milho. Scientia Agraria, Curitiba,.11: 481-486.

Bentancourt, C.M., Scatoni, I.B., 1995. Lepidopteros de inportancia econômica em el Uruguay (reconocimiento, biologia y daños de las plagas agrícolas y florestales). Montevideo: Hemisferio Sur: Facultad de Agronomia, 1, s. 122.

Borchert, D.M., Stinner, R.E., Walgenbach, J.F., Kennedy, G.G., 2004. Oriental fruit moth (Lepidoptera: Tortricidae) phenology and management with methoxyfenozide in North Carolina apples. Journal of Economical Entomology. 97 (4): 1353-1364.

Botton, M., Nava, D.E., Arioli, C.J., Grutzmacher, A.D., Garcia, M.S., 2011. Bioecologia, monitoramento e controle da Mariposa-Oriental na cultura do pessegueiro no Rio Grande do Sul. Circular Tecnica. 86: 111.

Chapman, P. J. and Lienk, S. E., 1971. Tortricid fauna of apple in New York (Lepidoptera: Tortricidae); including an account of apples occurrence in the State, especially as a naturalized plant. Special Publication March 1971, Geneva: New York State Agric. Exp. Station, Cornell University, 7 Ithaca, NY, USA.

Choi, K.H., Lee, S.W., Lee, D.H., Kim, D.A., Kim, S.K., 2008. Recent occurrence status of two major fruit moths, oriental fruit moth and peach fruit moth in apple orchards. Korean Journal of Applied Entomology. 47: 17-22.

Damos, P.T. and Savopoulou-Soultani, M., 2010. Development and statistical evaluation of models in forecasting moth phenology of major lepidopterous peach pest complex for integrated pest management programs. Crop. Prot. 29: 1190-1199.

Du, J., Li, G., Xu, X., We, J., 2015. Development and fecundity performance of oriental fruit moth (Lepidoptera: Tortricidae) reared on shoots and fruits of peach and pear in different seasons. Environmental Entomology. 44 (6): 1522-1530.

Elbert, A., Haas, M., Springer, B., Thielert, W., Nauen, R.. 2008. Applied aspects of neonicotinoid uses in crop protection. Pest Manag. Sci. 64: 1099-1105.

Ertop, S. and A. Özpınar, 2007. Çanakkale ili kiraz bahçelerindeki zararlı ve yararlı türler ile önemli zararlı türlerin popülasyon gelişmesinin belirlenmesi. Türkiye II. Bitki Koruma Kongresi, 27-29 Ağustos 2007. Isparta, s. 75 (Özet).

Gençsoylu İ., Akşit T, Ozer G., Cacamer A., Başpınar N., 2006. Population dynamics and damage on shoots and fruits caused by of Grapholita molesta Busck (Lep.:Tortricidae), Anarsia lineatella Zell. (Lep.:Gelechiidae) and Ceratitis capitata Wied. (Dip.:Tephritidae) in some peach varieties. Asian Journal of Plant Sciences. 5 (3): 487-491.

Gonzalez, R.H., 1993. Sistemas de monitoreo y manejo de las polillas da fruta (Cydia molesta y C. pomonella). Santiago: Universidad de Chile, p. 60.

Jones, M. M., Robertson, J. L., Weinzierl, R. A.,2010. Susceptibility of oriental fruit moth (Lepidoptera: Tortricidae) larvae to selected reduced-risk insecticides. Journal of Economic Entomology. 103: 18151820.

Kanga, L., Pree, D., van Lier, J., Walker, G., 2003. Management of insecticide resistance in oriental fruit moth (Grapholita molesta; Lepidoptera: Tortricidae) populations from Ontario. Pest Manag. Sci. 59: 921-927. 
Kim, D.-S., Boo, K.S., Jeong, H.Y., 2004. Evaluation of pheromone lure of Grapholita molesta (Lepidoptera: Tortricidae) and forecasting its phenological events in Suwon. Korean Journal of Applied Entomology. 43: 281-289.

Kim, Y., Bae, S., Son, Y., Park, J., 2009. Analysis of migration of the oriental fruit moth, Grapholita molesta, in apple-cultivating areas based on population monitoring using sex pheromone and RAPD molecular marker. Korean Journal of Applied Entomology. 48: 211-219.

Kirk, H., Dorn, S., Mazzi, D., 2013. Worldwide population genetic structure of the oriental fruit moth (Grapholita molesta), a globally invasive pest. BMC Ecology. 13:12.

Kovanci, O., and Walgenbach, J., 2005. Monitoring The oriental fruit moth with pheromone and bait traps in apple orchards under different management regimes. Int. J. Pest. Manag. 24: 273-279.

Kovanc1, O.B., Schal, C., Walgenbach, J.F., Kennedy, G.G., 2006. Effects of pheromone loading, dispenser age, and trap height on pheromone trap catches of the oriental fruit moth in apple orchards. Phytoparasitica. 34(3):252-260.

Kyparissoudas, D.S., 1989. Control of Cydia molesta (Busck) by mating disruption using isomate-m pheromone dispensers in Northern Greece. Entomologia Hellenica. 7: 3-6.

Myers, C.T., Hull, L.A., Krawczyk, G., 2006a. Comparative survival rates of oriental fruit moth (Lepidoptera: Tortricidae) larvae on shoots and fruit of apple and peach. Journal of Economical Entomology. 99(4): 1299-1309.

Neto e Silva, O.A.B., Botton, M., Garcia, M.S., Bisognin, A.Z., Nava, D.E., 2010. Desenvolvimento e reprodução da mariposa oriental em macieira e pessegueiro. Pesquisa Agropecuária Brasileira, Brasília. 45(10): 1082-1088.

Özpınar A., Özbek, İ., Şahin., A.K., 2014. Adult population fluctuation of Oriental fruit moth, Grapholita molesta (Lep.: Tortricidae), in peach orchards of Çanakkale, Turkey. Journal of Entomological Society of Iran. 34(3):1-8.

Özpınar, A., Şahin, A.K., Polat, B., Özbek, İ., 2012. Çanakkale ili meyve alanlarında Grapholita molesta Busck, 1916, (Lepidoptera: Tortricidae)'nın yayılışı ve ergin popülasyon değişimi. Bitki Koruma Bülteni. 52(1): 71-80.

Rothschild, G.H.L. and Vickers, R.A., 1991. Biology, ecology and control of the oriental fruit moth. In: van der Geest, L.P.S., Evenhuis, H.H. (Eds.), Tortricid pests: Their biology, natural enemies and control: World crop pests. 5:389-412.

Salles, L.A.B., 1991. Grapholita (Grapholita molesta): Bioecologia e controle. Pelotas: Embrapa-CNPFT, s. 13 (Embrapa-CNPFT. Documentos, 42).

Sarker, S. and Lim, U.T., 2019. Development and fecundity performance of Grapholita molesta and Grapholita dimorpha (Lepidoptera: Tortricidae) on different immature fruits. PLoS ONE. 14(5): e0217492. https://doi.org/10.1371/journal.pone.0217492.

Siegwart, M., Monteiro, L.B., Maugin, S., Olivares, J., Malfitano, C.S., Sauphanor, B., 2011. Tools for resistance monitoring in oriental fruit moth (lepidoptera: tortricidae) and first assessment in brazilian populations. Journal of Economic Entomology. 104 (2): 636-645.

Stearns, L.A., 1920. Experiments on the control of the oriental fruit moth. (Laspeyresia molesta Busck). Q. Bull. VA State Crop Pest Commission. 2: 3-16.

Yang, C.Y., Han, K.S., Boo, K.S., 2001. Occurrence of and damage by the oriental fruit moth, Grapholita molesta (Busck) (Lepidoptera: Tortricidae) in pear orchards. Korean Journal of Applied Entomology. 40: 117-123.

Yang, C.Y., Jung, J.K., Han, K.S., Boo, K.S., Yiem, M.S., 2002. Sex pheromone composition and monitoring of the oriental fruit moth, Grapholita molesta (Lepidoptera: Tortricidae) in Naju pear orchards. Journal of Asia-Pacific Entomology. 5: 201-207. 